\title{
Proteomic Analysis of the Ontogenetic Variability in Plasma Composition of Juvenile and Adult Bothrops jararaca Snakes
}

\author{
Karen de Morais-Zani, ${ }^{1,2}$ Kathleen Fernandes Grego,' \\ Aparecida Sadae Tanaka, ${ }^{3}$ and Anita Mitico Tanaka-Azevedo ${ }^{1,2}$ \\ ${ }^{1}$ Laboratório de Herpetologia, Instituto Butantan, Avenida Vital Brazil 1500, \\ 05503-900 São Paulo, SP, Brazil \\ ${ }^{2}$ Programa de Pós-Graduação Interunidades em Biotecnologia, Universidade de São Paulo, \\ Avenida Professor Lineu Prestes 2415, 05508-900 São Paulo, SP, Brazil \\ ${ }^{3}$ Departamento de Bioquímica, Universidade Federal de São Paulo, Rua Três de Maio 100, \\ 04044-020 São Paulo, SP, Brazil
}

Correspondence should be addressed to Anita Mitico Tanaka-Azevedo; amt.azevedo@uol.com.br

Received 18 January 2013; Revised 1 April 2013; Accepted 3 April 2013

Academic Editor: Djuro Josic

Copyright (C) 2013 Karen de Morais-Zani et al. This is an open access article distributed under the Creative Commons Attribution License, which permits unrestricted use, distribution, and reproduction in any medium, provided the original work is properly cited.

\begin{abstract}
The ontogenetic variability in venom composition of some snake genera, including Bothrops, as well as the biological implications of such variability and the search of new molecules that can neutralize the toxic components of these venoms have been the subject of many studies. Thus, considering the resistance of Bothrops jararaca to the toxic action of its own venom and the ontogenetic variability in venom composition described in this species, a comparative study of the plasma composition of juvenile and adult $B$. jararaca snakes was performed through a proteomic approach based on $2 \mathrm{D}$ electrophoresis and mass spectrometry, which allowed the identification of proteins that might be present at different levels during ontogenetic development. Among the proteins identified by mass spectrometry, antihemorrhagic factor Bj46a was found only in adult plasma. Moreover, two spots identified as phospholipase $A_{2}$ inhibitors were significantly increased in juvenile plasma, which can be related to the higher catalytic PLA activity shown by juvenile venom in comparison to that of adult snakes. This work shows the ontogenetic variability of $B$. jararaca plasma, and that these changes can be related to the ontogenetic variability described in its venom.
\end{abstract}

\section{Introduction}

Poisonous snakes are responsible for around 50,000 deaths among five million cases of ophidian accidents per year in the world, especially in the rural areas of tropical countries in Asia, Africa, and South America [1,2].

Envenomation by Viperidae snakes causes local tissue damages such as edema, hemorrhage, and myonecrosis, which are not well neutralized by conventional antivenom serotherapy [3]. Bothrops jararaca (B. jararaca) snake belongs to the Viperidae family and is the main reason for ophidian accidents in the state of São Paulo, Brazil [4]. Its victims usually have, besides systemic reactions of envenomation such as bleeding and blood incoagulability, local effects at the bite site such as edema, ecchymoses, compartmental syndrome, blisters, and necrosis [5]. The envenomation symptomatology has always stimulated researches on snake venom composition and function.

Unfortunately, the same is not observed for snake plasma. Despite extensive biochemical and molecular characterization of blood coagulation in mammals, little information is available about haemostasis in other vertebrates [6], although there is an increasing interest in the "natural resistance" of snakes towards the toxicity of its own venom and towards other snake venoms. The inter- and intraspecies resistibility can contribute to the development of new strategies for 


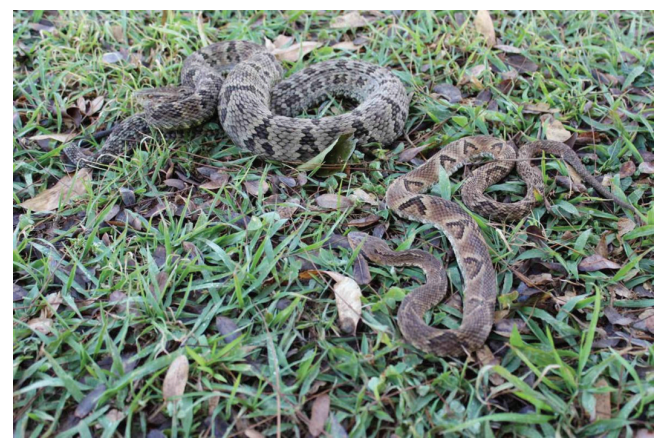

FIgURE 1: Adult and juvenile B. jararaca specimens.

the treatment of snake envenomation and the discovery of proteins that can neutralize the toxic components of these venoms [7], making snake plasma a rich source of bioactive molecules.

It has been proposed that there are two different mechanisms that may account for this "natural immunity" [8]: (i) mutation of the gene encoding the target of the venom toxin, providing target resistance to the toxin [9-12] or (ii) presence of proteins that neutralize hemorrhagins [13-16], neurotoxins [17-22], or myotoxins [23, 24] in the blood of resistant animals. Several studies have shown that these proteins are either metalloproteinase inhibitors (antihemorrhagic factors) or $\mathrm{PLA}_{2}$ inhibitors (PLIs) (antineurotoxic/antimyotoxic factors) $[8,25-28]$.

Our group has purified and characterized two proteins from the plasma of $B$. jararaca snake, probably involved in its self-defense against accidental envenomation: (i) BjI, a blood coagulation inhibitor that recognizes thrombin-like enzymes present in $B$. jararaca venom by western blotting, suggesting a protective role of this protein [29] and (ii) fibrinogen [30], which showed resistance to hydrolysis caused by snake venoms. Interestingly, while bovine thrombin coagulated both $B$. jararaca and human fibrinogen, $B$. jararaca venom clotted human fibrinogen, but not $B$. jararaca fibrinogen. In addition, $C$. durissus terrificus and Lachesis sp. venoms could also clot human fibrinogen, with no action upon B. jararaca fibrinogen [31].

Another interesting feature described in some snake species is the ontogenetic variability in venom composition, a well-documented phenomenon that has long been studied [32]. Ontogenetic variation in venom composition has been reported in a number of genera [33-37], including Bothrops snakes [32, 38-41], which accounts for the differences in the clinical manifestations and severity of envenomation by juvenile and adult B. jararaca [42].

All the peculiarities related to ontogenetic variation in $B$. jararaca venom raised the question of whether the plasma composition of snakes follows the same modifications described in the venom. Therefore, a comparative study of the plasma composition of juvenile and adult $B$. jararaca snake was carried out. The present study focused on the antivenom proteins, considering their importance for the self-protection of these animals and for the search of new proteins for antivenom treatment.

\section{Material and Methods}

2.1. Blood Collection. Six specimens of B. jararaca ( 3 juveniles and 3 adults) from the Laboratory of Herpetology, Butantan Institute, São Paulo, Brazil, were used for this analysis. All specimens were females, juveniles $(<60 \mathrm{~cm}$ snoutvent length) or adults (>82 cm snout-vent length) $[43,44]$ (Figure 1). Blood was collected by caudal venipuncture. Citrated blood samples were collected in a 9:1 ratio of blood to $3.8 \%$ sodium citrate solution, and plasma was obtained by blood centrifugation for $15 \mathrm{~min}$ at 1,200 $\mathrm{g}$ at room temperature and stored at $-20^{\circ} \mathrm{C}$. The Committee for the Ethical Use of Animals of Butantan Institute approved the experimental protocols (Protocol no. 542/08).

2.2. Protein Determination. Protein concentrations were determined using bicinchoninic acid (Sigma, St. Louis, MO, USA) and bovine serum albumin (BSA) (Sigma, St. Louis, MO, USA) as a standard, according to Smith et al. [45].

\subsection{Two-Dimensional Electrophoresis (2D Electrophoresis).} Two-Dimensional electrophoresis was used to separate proteins in the first dimension by isoelectric focusing (IEF) and in the second dimension by molecular weight using SDSPAGE electrophoresis. IEF was carried out using precast Immobiline DryStrip gels $\mathrm{pH}$ 3-10 gradient (24 cm-IPG strip) using an IPGphor unit (GE Healthcare, Uppsala, Sweden). On each gel, $1 \mathrm{mg}$ of protein was loaded. The IPG strip and sample were covered with Dry Strip Cover Fluid (GE Healthcare, Uppsala, Sweden) and run at constant voltage of $100 \mathrm{~V}$ for $12 \mathrm{~h}$ and $500 \mathrm{~V}$ up to the accumulation of $500 \mathrm{Vh}$, followed by gradient voltage from 500 to $1,000 \mathrm{~V}$ up to the accumulation of $800 \mathrm{Vh}$, another gradient voltage from 1,000 to $10,000 \mathrm{Vh}$ up to the accumulation of $16,500 \mathrm{Vh}$, and constant voltage of $10,000 \mathrm{~V}$ up to the accumulation of $22,200 \mathrm{Vh}$. IEF was followed by a SDS-PAGE using $10 \%$ resolving gels, according to Laemmli protocol [46], and DALTsix system (GE Healthcare, Uppsala, Sweden). The gels were run at constant amperage of $15 \mathrm{~mA}$ and constant voltage of $80 \mathrm{~V}$ for $1 \mathrm{~h}$ and then constant amperage of $60 \mathrm{~mA}$ and constant voltage of $500 \mathrm{~V}$. Protein spots were visualized using Coomassie Blue R350 staining procedure according to GE Healthcare (Uppsala, Sweden) protocol. Each sample was analyzed in triplicate. Image acquisition of gels was performed using the ImageScanner III densitometer (GE Healthcare, Uppsala, Sweden) and the gels were analyzed using ImageMaster Platinum 7.0 software (GE Healthcare, Uppsala, Sweden). The spots were quantified using the $\%$ of spot volume criterion, which is automatically calculated by the ImageMaster software. The match analysis was performed in an automatic mode, and further manual editing was performed to correct mismatched and unmatched spots. A criterion of $P<0.05$ was used to define the significant difference when analyzing the paired spots between the two groups $(n=3)$ according to ANOVA.

2.4. Protein Identification. For identification of spots with quantitative variation by mass spectrometry, gel spots were 


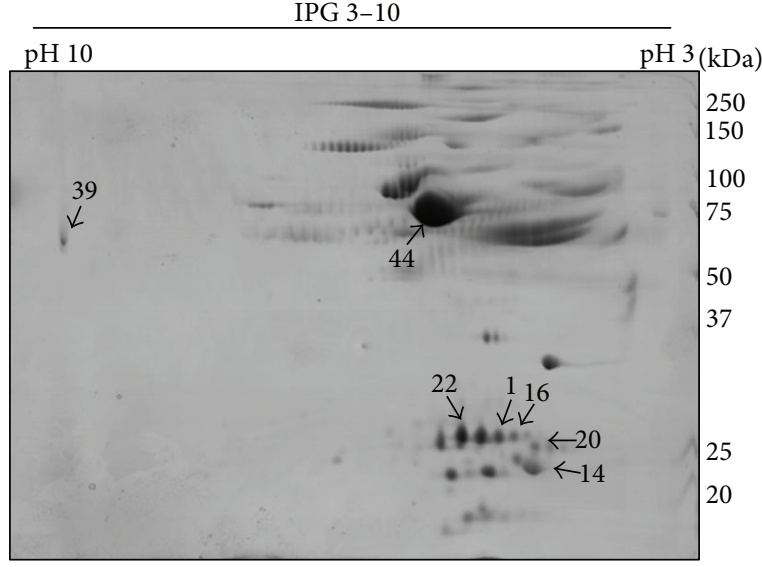

(a)

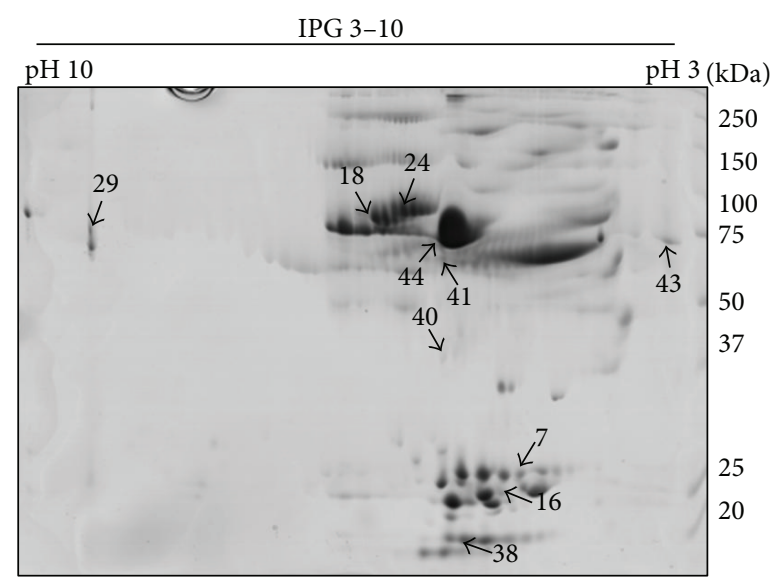

(b)

FIGURE 2: Analysis of juvenile and adult B. jararaca plasma by 2D electrophoresis. Plasma proteins (1 mg) from (a) juvenile and (b) adult were submitted to isoelectric focusing on 3-10 IPG strips $(24 \mathrm{~cm})$ followed by 10\% SDS-PAGE. Gels were stained with Coomassie Blue R350. Spots present at different levels were indicated with arrows and identified by nanoESI-Q-TOF.

excised and in-gel trypsin digestion was performed according to Shevchenko et al. [47]. An aliquot $(4.5 \mu \mathrm{L})$ of the peptide mixture was separated by $\mathrm{C}_{18}(100 \mu \mathrm{m} \times 100 \mathrm{~mm}) \mathrm{RP}$-nano UPLC (nanoAcquity UPLC, Waters, Milford, MA, USA) coupled with a Q-TOF Ultima mass spectrometry (Waters, Milford, MA, USA) with a nanoelectrospray source at flow rate of $600 \mathrm{~nL} / \mathrm{min}$. The gradient condition was $15-90 \%$ acetonitrile in $0.1 \%$ formic acid over $10 \mathrm{~min}$. The instrument was operated in the "top three" mode, in which one MS spectrum is acquired followed by MS/MS of the top three mostintense peaks detected. The resulting spectra were acquired using MassLynx v. 4.1 software, and the raw data files were converted into a peak list format (mgf) without summing the scans using Mascot Distiller 2.2.1.0, 2008, Matrix Science (Matrix Science Ltd., London, UK) and searched against nonredundant protein database (NCBI) using Mascot, with carbamidomethylation as fixed modification and oxidation of methionine as variable modifications, one trypsin missed cleavage and tolerance of $20 \mathrm{ppm}$ for both precursor and fragment ions.

\section{Results and Discussion}

It is known that many venomous snakes are resistant to their own venoms and that this natural resistance is due to the neutralizing factors present in their plasma. In the last years, studies on animals that resist the action of snake venoms have led to the discovery and characterization of proteins responsible for this resistance. The result of these studies was the structural and functional characterization of protein inhibitors of hemorrhagic metalloproteinases, as well as myotoxic and neurotoxic PLA 2 [7].

Although specific endogenous inhibitors for snake venom have been widely described in the literature and have been the subject of review articles $[25,48,49]$, the correlation between venom and plasma ontogenetic development has not been reported yet.
TABLE 1: Number of matches and spots present at different levels in juvenile and adult $B$. jararaca plasma. 2D electrophoresis were analyzed by ImageMaster Platinum 7.0 software (GE Healthcare).

\begin{tabular}{|c|c|c|c|}
\hline & \multirow{2}{*}{$\begin{array}{l}\text { Number of } \\
\text { matches }\end{array}$} & \multicolumn{2}{|c|}{$\begin{array}{c}\text { Spots showing quantitative } \\
\text { variation }\end{array}$} \\
\hline & & $\begin{array}{c}\text { Exclusive } \\
\text { spots }\end{array}$ & $\begin{array}{c}\text { Increased } \\
\text { spots }\end{array}$ \\
\hline Juvenile $B$. jararaca & \multirow{2}{*}{1,250} & 18 & 5 \\
\hline Adult B. jararaca & & 16 & 6 \\
\hline & & \multicolumn{2}{|c|}{ Total: 45} \\
\hline
\end{tabular}

Plasma from juvenile and adult $B$. jararaca were analyzed by $2 \mathrm{D}$ electrophoresis and were compared using ImageMaster Platinum 7.0 software (see experimental section for details). Figure 2 shows that the proteomic profile of juvenile and adult snakes is similar, suggesting minor ontogenetic differences between the plasma protein content of these two stages of development. The number of matches represents the spots identified in juvenile and adult plasma and exclusive spots were considered those present in only one group, juvenile or adult plasma. The results showed 1,250 matches between juvenile and adult plasma, with only 45 spots showing quantitative variation $(P<0.05)$. Taking into account these 45 spots, 18 are exclusive for juvenile and 16 for adult snakes. In addition, 5 spots were increased in juvenile and 6 in adults (Table 1), suggesting that the ontogenetic development is associated to little changes in the protein content of the plasma.

In order to identify spots present in different levels and correlate these differences to the snake development, the corresponding spots were excised, in-gel digested with trypsin, and submitted to mass spectrometry (MS/MS) (Table 2 and Figure 2). It is important to emphasize that only spots showing quantitative variation were submitted to MS/MS analysis. In addition, out of 45 spots analyzed, only 17 were identified, 
TABLE 2: Identification of spots showing quantitative variation in juvenile and adult B. jararaca plasma indicated in Figure 2, by ESI-Q-TOF (MS/MS).

(a)

\begin{tabular}{|c|c|c|c|c|c|}
\hline \multirow[b]{2}{*}{$\begin{array}{l}\text { Spot } \\
\text { number }^{\mathrm{a}}\end{array}$} & \multicolumn{4}{|c|}{ Juvenile Bothrops jararaca snake } & \multirow[b]{2}{*}{$\begin{array}{l}\text { Volume } \\
\quad(\%)\end{array}$} \\
\hline & Protein name (organism) & Score & $\begin{array}{c}\text { Protein accession } \\
\text { number }^{\mathrm{b}}\end{array}$ & Peptide sequences $^{c}$ & \\
\hline 1 & $\begin{array}{c}\gamma \text {-phospholipase } \mathrm{A}_{2} \text { inhibitor } \\
(\text { Bothrops jararaca) }\end{array}$ & 556 & gi|157885066 & $\begin{array}{l}\text { KCIDIVGHR } \\
\text { KNCFSSSICKL } \\
\text { SCDFCHNIGK } \\
\text { VFLEISSASLSVR } \\
\text { HEHFPGDIAYNLK } \\
\text { LGQIDVNIGHHSYIR } \\
\text { DCDGYQQECSSPEDVCGK } \\
\text { CIDIVGHRHEHFPGDIAYNLK }\end{array}$ & 1.6137 \\
\hline 14 & $\begin{array}{c}\gamma \text {-phospholipase } \mathrm{A}_{2} \text { inhibitor } \\
\text { subunit } \mathrm{B} \\
(\text { Trimeresurus flavoviridis) }\end{array}$ & 120 & gi|155676753 & $\begin{array}{l}\text { RACCVGDECK } \\
\text { GCATESLCTLLQK }\end{array}$ & 1.6347 \\
\hline 16 & $\begin{array}{c}\gamma \text {-phospholipase } \mathrm{A}_{2} \text { inhibitor } \\
(\text { Bothrops jararaca) }\end{array}$ & 467 & gi|157885066 & $\begin{array}{l}\text { KCIDIVGHR } \\
\text { NCFSSSICK } \\
\text { VFLEISSASLSVR } \\
\text { HEHFPGDIAYNLK } \\
\text { TVHKNCFSSSICK } \\
\text { LGQIDVNIGHHSYIR } \\
\text { DCDGYQQECSSPEDVCGK } \\
\text { KCIDIVGHRHEHFPGDIAYNLK }\end{array}$ & 0.5292 \\
\hline 20 & $\begin{array}{c}\gamma \text {-phospholipase } \mathrm{A}_{2} \text { inhibitor } \\
\text { subunit } \mathrm{B} \\
\text { (Trimeresurus flavoviridis) }\end{array}$ & 284 & gi|155676753 & $\begin{array}{l}\text { ACCVGDECK } \\
\text { RACCVGDECK } \\
\text { DTENQCLSLTGK } \\
\text { GCATESLCTLLQK } \\
\end{array}$ & 0.5687 \\
\hline 22 & $\begin{array}{c}\gamma \text {-phospholipase } \mathrm{A}_{2} \text { inhibitor } \\
(\text { Bothrops jararaca) }\end{array}$ & 496 & gi|157885068 & $\begin{array}{l}\text { INCCEK } \\
\text { KCIDIVGHR } \\
\text { GRINCCEK } \\
\text { NCFSSSICK } \\
\text { VFLEISSASLSVR } \\
\text { HEHFPGDIAYNLK } \\
\text { TVHKNCFSSSICK } \\
\text { LGQIDVNIGHHSYIR } \\
\text { KCIDIVGHRHEHFPGDIAYNLK }\end{array}$ & 3.5287 \\
\hline 39 & $\begin{array}{l}\text { C3 complement } \\
\text { (Naja naja) }\end{array}$ & 221 & gi|399269 & $\begin{array}{l}\text { RVGLVAVDK } \\
\text { IWDTIEK } \\
\text { IQKPGAAMK } \\
\text { GIYTPGSPVR } \\
\text { IKLEGDPGAR } \\
\text { AVYVLNDKYK } \\
\text { EYVLPSFEVR } \\
\end{array}$ & 0.1644 \\
\hline 44 & $\begin{array}{c}\text { Albumin } \\
\text { (Trimeresurus flavoviridis) }\end{array}$ & 92 & gi|56790036 & $\begin{array}{l}\text { LVEDIQNDHIIQ } \\
\text { IIPQAPTSNLIEITKR }\end{array}$ & 0.3461 \\
\hline
\end{tabular}

(b)

Adult Bothrops jararaca snake

\begin{tabular}{|c|c|c|c|c|c|}
\hline $\begin{array}{l}\text { Spot } \\
\text { number }^{\mathrm{a}}\end{array}$ & Protein name (organism) & Score & $\begin{array}{c}\text { Protein accession } \\
\text { number }\end{array}$ & Peptide sequences & $\begin{array}{l}\text { Volume }^{c} \\
(\%)\end{array}$ \\
\hline 7 & $\begin{array}{c}\gamma \text {-phospholipase } \mathrm{A}_{2} \text { inhibitor } \\
\text { (Bothrops jararaca) }\end{array}$ & 511 & gi|157885066 & $\begin{array}{l}\text { KCIDIVGHR } \\
\text { NCFSSSICK } \\
\text { VFLEISSASLSVR } \\
\text { HEHFPGDIAYNLK } \\
\text { LGQIDVNIGHHSYIR } \\
\text { DCDGYQQECSSPEDVCGK } \\
\text { KCIDIVGHRHEHFPGDIAYNLK }\end{array}$ & 0.5813 \\
\hline
\end{tabular}


(b) Continued.

\begin{tabular}{|c|c|c|c|c|c|}
\hline \multirow[b]{2}{*}{$\begin{array}{l}\text { Spot } \\
\text { number }^{\mathrm{a}}\end{array}$} & \multicolumn{4}{|c|}{ Adult Bothrops jararaca snake } & \multirow[b]{2}{*}{$\begin{array}{c}\text { Volume } \\
(\%)\end{array}$} \\
\hline & Protein name (organism) & Score & $\begin{array}{c}\text { Protein accession } \\
\text { number }^{\mathrm{b}}\end{array}$ & Peptide sequences & \\
\hline 16 & $\begin{array}{c}\gamma \text {-phospholipase } \mathrm{A}_{2} \text { inhibitor } \\
(\text { Bothrops jararaca) }\end{array}$ & 470 & gi|157885066 & $\begin{array}{l}\text { KCIDIVGHR } \\
\text { NCFSSSICK } \\
\text { SCDFCHNIGK } \\
\text { VFLEISSASLSVR } \\
\text { HEHFPGDIAYNLK } \\
\text { LGQIDVNIGHHSYIR } \\
\text { DCDGYQQECSSPEDVCGK }\end{array}$ & 0.0990 \\
\hline 18 & $\begin{array}{c}\text { Transferrin } \\
\text { (Lamprophis fuliginosus) }\end{array}$ & 220 & gi|108792441 & $\begin{array}{l}\text { IVWCAVGK } \\
\text { VCTFHTHDW } \\
\text { EADAITLDGGHIYTAGK }\end{array}$ & 0.4829 \\
\hline 24 & $\begin{array}{c}\text { Transferrin } \\
\text { (Lamprophis fuliginosus) }\end{array}$ & 232 & gi|108792441 & $\begin{array}{l}\text { LVLEQQK } \\
\text { IVWCAVGK } \\
\text { VCTFHTHDW } \\
\text { EADAITLDGGHIYTAGK }\end{array}$ & 0.2124 \\
\hline 29 & $\begin{array}{l}\text { C3 complement } \\
\text { (Naja naja) }\end{array}$ & 363 & gi|399269 & $\begin{array}{l}\text { VGLVAVDK } \\
\text { LEGDPGAR } \\
\text { IWDTIEK } \\
\text { IQKPGAAMK } \\
\text { GIYTPGSPVR } \\
\text { IKLEGDPGAR } \\
\text { DTCMGTLVVK } \\
\text { AVYVLNDKYK } \\
\text { EYVLPSFEVR }\end{array}$ & 0.2256 \\
\hline 38 & $\begin{array}{c}\alpha \text {-phospholipase } \mathrm{A}_{2} \text { inhibitor } \\
\text { precursor } \\
(\text { Bothrops jararaca })\end{array}$ & 383 & gi|167547111 & $\begin{array}{l}\text { LYVTNK } \\
\text { REFANLR } \\
\text { KNFEALR } \\
\text { RSFGSGSER } \\
\text { GAFLTVHKA } \\
\text { KAFANVLER } \\
\text { KVLNSLIDALMHLQRE } \\
\text { QICEQAEGHIPSPQLENHNK }\end{array}$ & 0.1067 \\
\hline 40 & $\begin{array}{c}\beta \text {-Actin } \\
\text { (Rachycentron canadum) }\end{array}$ & 867 & gi|161376754 & $\begin{array}{l}\text { AGFAGDDAPR } \\
\text { DLTDYLMK } \\
\text { GYSFTTTAER } \\
\text { EITALAPSTMK } \\
\text { AVFPSIVGRPR } \\
\text { DSYVGDEAQSKR } \\
\text { IWHHTFYNELR } \\
\text { QEYDESGPSIVHR } \\
\text { LDLAGRDLTDYLMK } \\
\text { SYELPDGQVITIGNER } \\
\text { EEEIAALVVDNGSGMCK } \\
\text { VAPEEHPVLLTEAPLNPK } \\
\text { DLYANTVLSGGTTMYPGIADR } \\
\text { TTGIVMDSGDGVTHTVPIYEGYALPHAILR }\end{array}$ & 0.0060 \\
\hline 41 & $\begin{array}{l}\text { Antihemorrhagic factor Bj46a } \\
\text { (Bothrops jararaca) }\end{array}$ & 68 & gi|48428681 & $\begin{array}{l}\text { YALNVIKN } \\
\text { EGHAHSHLIQQHVEK } \\
\text { NCPKCPILLPSNNPQVVDSVEYVLNKHNEK } \\
\text { HNEKLSDHVYEVLEISR } \\
\text { GDLECDEKDAKEWTDTGVR } \\
\text { IMFNVDTFKEDVFAK } \\
\text { LSDHVYEVLEISR } \\
\text { VPVAFVK } \\
\text { ELPKDISDR } \\
\text { VHHFEL } \\
\text { EWTDTGVR }\end{array}$ & 0.09264 \\
\hline
\end{tabular}


(b) Continued.

Adult Bothrops jararaca snake

\begin{tabular}{|c|c|c|c|c|c|}
\hline $\begin{array}{l}\text { Spot } \\
\text { number }^{a}\end{array}$ & Protein name (organism) & Score & $\begin{array}{c}\text { Protein accession } \\
\text { number }^{\mathrm{b}}\end{array}$ & Peptide sequences & $\begin{array}{c}\text { Volume } \\
(\%)\end{array}$ \\
\hline 43 & $\begin{array}{c}\text { Albumin } \\
\text { (Trimeresurus flavoviridis) }\end{array}$ & 234 & gi|56790036 & $\begin{array}{l}\text { ECFDTK } \\
\text { YGINDCCAK } \\
\text { LVEDIQNDHIIQ } \\
\text { QLCHCCDSSFISR } \\
\text { LEDHVQCLHTGEEQLK }\end{array}$ & 0.0497 \\
\hline 44 & $\begin{array}{c}\text { Albumin } \\
\text { (Trimeresurus flavoviridis) }\end{array}$ & 235 & gi|56790036 & $\begin{array}{l}\text { FIETHEK } \\
\text { NNCDNYK } \\
\text { LVEDIQNDHIIQ } \\
\text { QLCHCCDSSFISR } \\
\text { LEDHVQCLHTGEEQLK }\end{array}$ & 0.3964 \\
\hline
\end{tabular}

Spot number refers to that shown in Figure 2.

${ }^{\mathrm{b}} \mathrm{NCBI}$ accession number.

${ }^{\mathrm{c}}$ Obtained by MS/MS analysis.

${ }^{\mathrm{d}} P<0.05$.

7 in juvenile and 10 in adult plasma. During this process, we faced the limited available information about reptilian genome and proteome, described by other authors [50, 51]; thus, this study identified proteins by sequence homologies through the National Center for Biotechnology Information database (NCBI).

Among the proteins identified, transferrin was classified as increased in adult plasma (spot no. 18). This could be due to a differential iron transport mechanism across the development stage of snakes, as also reported for humans [52].

The complement system of snakes is of particular interest because the venom of Naja naja and related Asian snakes of the genus Naja [53] and the venom of Austrelaps superbus [54], an Australian elapid, contain a C3 structural and functional analog, cobra venom factor (CVF). Functionally, CVF resembles the $\mathrm{C} 3$ activation product $\mathrm{C} 3 \mathrm{~b}$ as it forms a complex with $\mathrm{B}$ factor in the presence of $\mathrm{Mg}^{2+}$ [55]. CFV and its analogs have become an important research tool in order to study the role of complement in host defense, immune response, and disease pathogenesis [53].

In B. jararaca plasma, C3 complement was identified in juvenile and adult plasma (Figure 2-spots 39 and 29, resp.) with a slight difference concerning the molecular weights. MS/MS analysis identified these spots as C3 complement by sequence homology to C3 from Naja naja (gi |399269). This protein, described in Naja naja, has molecular weight of $185 \mathrm{kDa}$ and theoretical pI of 5.9. In this work, the two spots identified as C3 complement have molecular mass around $75 \mathrm{kDa}$ and $\mathrm{pI}$ around 10 , suggesting the presence of fragments in our samples.

Another protein present in adults, according to analysis by $2 \mathrm{D}$ electrophoresis, is the antihemorrhagic factor $\mathrm{Bj} 46 \mathrm{a}$ (Figure 2-spot 41). Bj46a is a glycoprotein isolated from $B$. jararaca plasma that inhibits the snake venom metalloproteinases atrolysin $\mathrm{C}$ and jararhagin and $B$. jararaca venom hemorrhagic activity [56]. Interestingly, Antunes et al. [57] demonstrated that the venom of adult $B$. jararaca specimens was more hemorrhagic than the venom of newborn snakes.
The hemorrhagic activity present in B. jararaca venom is generally credited to P-III metalloproteinases, like jararhagin $[58,59]$. The reduced hemorrhagic activity present in the newborn B. jararaca venom described by Antunes et al. [57] appears to be correlated with the lack of jararhagin in newborn venom. This work showed the sequence of about $35 \%$ of $\mathrm{Bj} 46 \mathrm{a}$ (data not shown). All of the 122 amino acids identified showed identity to the corresponding sequence present in the databank. However, Bj46a was also identified in juvenile $B$. jararaca plasma submitted to $1 \mathrm{D}$ electrophoresis and analyzed by Fourier Transform Ion Cyclotron Resonance mass spectrometry (data not published), suggesting the presence of this inhibitor in juvenile and adult snakes. One hypothesis to explain this finding is that $\mathrm{Bj} 46 \mathrm{a}$ might be present in low levels in juvenile $B$. jararaca plasma and could not be identified by 2D electrophoresis. This finding linked to our results suggests a correlation between the ontogenetic development of the venom and the plasma composition of $B$. jararaca.

The high incidence of PLI identified among spots with quantitative variation is noteworthy. This protein corresponds to 71 and $30 \%$ of the total proteins identified in juvenile and adult plasma, respectively, and the present work showed that PLIs are increased in juvenile snakes (Figure 2spots, nos. 16 and 22).

Forty-nine percent of $\gamma$-PLI sequence was obtained in this study (data not shown). Out of 99 amino acids identified, only one has no identity to the corresponding sequence present in the databank. This is the first time that this protein is shown in $B$. jararaca, since the protein sequence described in UNIPROT databank (http://www.uniprot.org) was derived from DNA data. Moreover, $\alpha$-PLI was also possible to be identified, and about $48 \%$ of its sequence was obtained (data not shown). As seen for $\mathrm{Bj} 46 \mathrm{a}$, all of the 122 amino acids identified showed identity to the corresponding sequence present in the databank. It is noteworthy the high variability of PLIs found in juvenile or adult plasma, probably not only due to different glycosylation pattern but also to the amino acid sequence, as illustrated by spots 14 and 20 
(Figure 2), which are similar to Trimeresurus flavoviridis PLIs. This peculiarity is related to the high incidence of PLIs isoforms present in snake plasma, showing the physiological importance of these inhibitors for the physiology of these animals $[60,61]$.

The role played by PLIs has been the physiological protection of snakes against accidental envenomation or due to the feeding habits of ophiophagous specimens [8, 28, 60]. In the last two decades, the number of reports on endogenous PLIs in the plasma of snakes has increased, motivated by the need to develop potentially selective inhibitors for human $\mathrm{PLA}_{2}$.

Snake venom $\mathrm{PLA}_{2}$ exhibits a wide variety of pharmacological effects and is involved in the envenomation pathophysiology, presenting myotoxic and neurotoxic activities [62]. Antunes et al. [57] demonstrated that newborn B. jararaca venom shows catalytic $\mathrm{PLA}_{2}$ activity almost twice higher than that of the adult venom, and our results showed that the same occurs regarding $\gamma$-PLI, indicating a connection between venom and plasma components. In addition, besides the antivenom role of PLI, these proteins can be a favorable therapeutic approach in the treatment of inflammatory processes, once $\gamma$-PLI has been studied as a potential model for the development of selective inhibitors of proinflammatory $\mathrm{PLA}_{2}$ in humans $[60,63]$.

In short, the results showed that there are some differences in plasma protein composition between juvenile and adult $B$. jararaca and that these differences could be related to the ontogenetic variation of the venom composition. This is the first comparative study of protein profiles of juvenile and adult snake plasma. This approach is important for a better understanding of the ontogenetic development of B. jararaca. Moreover, associated with the knowledge of ontogenetic changes in venom composition and snakebite clinical reports, the differences identified could be used for the development of more specific antivenoms. It has been suggested that antiophidian serum could be enriched with natural antitoxins in order to increase the serum ability to neutralize snake venom [63]. Thus, the results presented here in this paper can contribute to the knowledge of antivenom mechanisms against ophidian accidents.

\section{Conflict of Interests}

The authors declare that there is no conflict of interests.

\section{Acknowledgments}

The authors acknowledge the Mass Spectrometry Laboratory at Brazilian Biosciences National Laboratory, CNPEMABTLuS, Campinas, Brazil for their support with the mass spectrometry analysis. This work was supported by Grants from Fundação de Amparo à Pesquisa do Estado de São Paulo (05/03514-9, 08/08140-8, 09/03484-3, 09/50199-2, 09/547089, 11/51857-3) and Conselho Nacional de Desenvolvimento Científico e Tecnológico.

\section{References}

[1] D. A. Warrell, "Clinical features of envenoming from snake bite," in Envenomings and Their Treatments, C. Bon and M. Goyffon, Eds., pp. 63-76, Fondation Marcel Mérieux, Lyon, France, 1996.

[2] J. P. Chippaux, "Snake-bites: appraisal of the global situation," Bulletin of the World Health Organization, vol. 76, no. 5, pp. 515$524,1998$.

[3] A. Ohsaka, "Hemorragic, necrotizing and edma-forming effects of snake venoms," in Snake Venoms, C. Y. Lee, Ed., pp. 480-546, Springer, Berlin, Germany, 1979.

[4] L. A. Ribeiro and M. T. Jorge, "Acidente por serpentes do gênero Bothrops: série de 3.139 casos," Revista da Sociedade Brasileira de Medicina Tropical, vol. 30, pp. 475-480, 1997.

[5] M. L. Santoro, I. S. Sano-Martins, H. W. Fan, J. L. Cardoso, R. D. G. Theakston, and D. A. Warrell, "Haematological evaluation of patients bitten by the jararaca, Bothrops jararaca, in Brazil," Toxicon, vol. 51, no. 8, pp. 1440-1448, 2008.

[6] L. Nahas, A. S. Kamiguti, F. Betti, I. S. Sano Martins, and M. I. Rodrigues, "Blood coagulation mechanism in the snakes Waglerophis merremii and Bothrops jararaca," Comparative Biochemistry and Physiology Part A, vol. 69, no. 4, pp. 739-743, 1981.

[7] S. Lizano, G. Domont, and J. Perales, "Natural phospholipase $\mathrm{A}_{2}$ myotoxin inhibitor proteins from snakes, mammals and plants," Toxicon, vol. 42, no. 8, pp. 963-977, 2003.

[8] G. Faure, "Natural inhibitors of toxic phospholipases $A_{2}$," Biochimie, vol. 82, no. 9-10, pp. 833-840, 2000.

[9] S. J. Burden, H. C. Hartzell, and D. Yoshikami, "Acetylcholine receptors at neuromuscular synapses: phylogenetic difference detected by snake $\alpha$ neurotoxins," Proceedings of the National Academy of Sciences of the United States of America, vol. 72, no. 8, pp. 3245-3249, 1975.

[10] D. Neumann, D. Barchan, M. Horowitz, E. Kochva, and S. Fuchs, "Snake acetylcholine receptor: cloning of the domain containing the four extracellular cysteines of the $\alpha$ subunit," Proceedings of the National Academy of Sciences of the United States of America, vol. 86, no. 18, pp. 7255-7259, 1989.

[11] B. Ohana, Y. Fraenkel, G. Navon, and J. M. Gershoni, "Molecular dissection of cholinergic binding sites: how do snakes escape the effect of their own toxins?" Biochemical and Biophysical Research Communications, vol. 179, no. 1, pp. 648-654, 1991.

[12] D. Barchan, S. Kachalsky, D. Neumann et al., "How the mongoose can fight the snake: the binding site of the mongoose acetylcholine receptor," Proceedings of the National Academy of Sciences of the United States of America, vol. 89, no. 16, pp. 77177721, 1992.

[13] T. Omori-Satoh, S. Sadahiro, A. Ohsaka, and R. Murata, "Purification and characterization of an antihemorrhagic factor in the serum of Trimeresurus flavoviridis, a crotalid," Biochimica et Biophysica Acta, vol. 285, no. 2, pp. 414-426, 1972.

[14] M. Ovadia, "Purification and characterization of an antihemorrhagic factor from the serum of the snake Vipera palaestinae," Toxicon, vol. 16, no. 6, pp. 661-672, 1978.

[15] S. Weissenberg, M. Ovadia, G. Fleminger, and E. Kochva, "Antihemorrhagic factors from the blood serum of the western diamondback rattlesnake Crotalus atrox," Toxicon, vol. 29, no. 7, pp. 807-818, 1991.

[16] S. Pichyangkul and J. C. Perez, "Purification and characterization of a naturally occurring antihemorrhagic factor in the serum of the hispid cotton rat (Sigmodon hispidus)," Toxicon, vol. 19, no. 2, pp. 205-215, 1981. 
[17] M. Ovadia, E. Kochva, and B. Moav, "The neutralization mechanism of Vipera palaestinae neurotoxin by a purified factor from homologous serum," Biochimica et Biophysica Acta, vol. 491, no. 2, pp. 370-386, 1977.

[18] C. L. Fortes-Dias, B. C. B. Fonseca, E. Kochva, and C. R. Diniz, "Purification and properties of an antivenom factor from the plasma of the South American rattlesnake (Crotalus durissus terrificus)," Toxicon, vol. 29, no. 8, pp. 997-1008, 1991.

[19] C. L. Fortes-Dias, Y. Lin, J. Ewell, C. R. Diniz, and T. Y. Liu, "A phospholipase $\mathrm{A}_{2}$ inhibitor from the plasma of the South American rattlesnake (Crotalus durissus terrificus). Protein structure, genomic structure, and mechanism of action," Journal of Biological Chemistry, vol. 269, no. 22, pp. 15646-15651, 1994.

[20] J. Perales, C. Villela, G. B. Domont et al., "Molecular structure and mechanism of action of the crotoxin inhibitor from Crotalus durissus terrificus serum," European Journal of Biochemistry, vol. 227, no. 1-2, pp. 19-26, 1995.

[21] J. Shao, H. Shen, and B. Havsteen, "Purification, characterization and binding interactions of the Chinese-cobra (Naja naja atra) serum antitoxic protein CSAP," Biochemical Journal, vol. 293, no. 2, pp. 559-566, 1993.

[22] W. Xiaolu, B. Havsteen, and H. Hansen, "Evidence of the coevolution of a snake toxin and its endogenous antitoxin cloning, sequence and expression of a serum albumin cDNA of the Chinese cobra," Biological Chemistry Hoppe-Seyler, vol. 376, no. 9, pp. 545-553, 1995.

[23] S. Lizano, B. Lomonte, J. W. Fox, and J. M. Gutiérrez, "Biochemical characterization and pharmacological properties of a phospholipase $A_{2}$ myotoxin inhibitor from the plasma of the snake Bothrops asper," Biochemical Journal, vol. 326, no. 3, pp. 853-859, 1997.

[24] S. Lizano, Y. Angulo, B. Lomonte et al., "Two phospholipase $\mathrm{A}_{2}$ inhibitors from the plasma of Cerrophidion (Bothrops) godmani which selectively inhibit two different group-II phospholipase $\mathrm{A}_{2}$ myotoxins from its own venom: isolation, molecular cloning and biological properties," Biochemical Journal, vol. 346, no. 3 , pp. 631-639, 2000.

[25] J. W. Fox and J. B. Bjarnason, "Metalloproteinase inhibitors," in Enzymes from Snake Venoms, G. S. Bailey, Ed., pp. 559-632, Alaken Inc, Fort Collins, Colo, USA, 1998.

[26] J. C. Pérez and E. E. Sánchez, "Natural protease inhibitors to hemorrhagins in snake venoms and their potential use in medicine," Toxicon, vol. 37, no. 5, pp. 703-728, 1999.

[27] J. Perales and G. B. Domont, "Are inhibitors of metallopreoteinases, phospholipase $\mathrm{A}_{2}$ and myotoxins members os the innate immune system?" in Perspectives in Molecular Toxinology, A. Ménez, Ed., Wiley, Chichester, UK, 2002.

[28] C. L. Fortes-Dias, "Endogenous inhibitors of snake venom phospholipases $\mathrm{A}_{2}$ in the blood plasma of snakes," Toxicon, vol. 40, no. 5, pp. 481-484, 2002.

[29] A. M. Tanaka-Azevedo, A. S. Tanaka, and I. S. Sano-Martins, "A new blood coagulation inhibitor from the snake Bothrops jararaca plasma: isolation and characterization," Biochemical and Biophysical Research Communications, vol. 308, no. 4, pp. 706-712, 2003.

[30] C. O. Vieira, "Bothrops jararaca fibrinogen and its resistance to hydrolysis evoked by snake venoms," Comparative Biochemistry and Physiology, vol. 151, no. 4, pp. 428-432, 2008.

[31] D. F. Vieira, L. Watanabe, C. D. Sant'ana et al., "Purification and characterization of jararassin-I, a thrombin-like enzyme from Bothrops jararaca snake venom," Acta Biochimica et Biophysica Sinica, vol. 36, no. 12, pp. 798-802, 2004.
[32] A. Zelanis, A. K. Tashima, M. M. T. Rocha et al., "Analysis of the ontogenetic variation in the venom proteome/peptidome of Bothrops jararaca reveals different strategies to deal with prey," Journal of Proteome Research, vol. 9, no. 5, pp. 2278-2291, 2010.

[33] S. A. Minton and S. A. Weinstein, "Geographic and ontogenic variation in venom of the western diamondback rattlesnake (Crotalus atrox)," Toxicon, vol. 24, no. 1, pp. 71-80, 1986.

[34] S. P. Mackessy, "Venom ontogeny in the pacific rattlesnakes Crotalus viridis helleri and C. v. oreganus," Copeia, vol. 1988, pp. 92-101, 1988.

[35] J. M. Gutierrez, C. Avila, Z. Camacho, and B. Lomonte, "Ontogenetic changes in the venom of the snake Lachesis muta stenophrys (bushmaster) from Costa Rica," Toxicon, vol. 28, no. 4, pp. 419-426, 1990.

[36] J. M. Gutierrez, M. C. Dos Santos, M. De Fatima Furtado, and G. Rojas, "Biochemical and pharmacological similarities between the venoms of newborn Crotalus durissus durissus and adult Crotalus durissus terrificus rattlesnakes," Toxicon, vol. 29, no. 10, pp. 1273-1277, 1991.

[37] P. Saravia, E. Rojas, V. Arce et al., "Geographic and ontogenic variability in the venom of the neotropical rattlesnake Crotalus durissus: pathophysiological and therapeutic implications," Revista de Biologia Tropical, vol. 50, no. 1, pp. 337-346, 2002.

[38] M. F. D. Furtado, M. Maruyama, A. S. Kamiguti, and L. C. Antonio, "Comparative study of nine Bothrops snake venoms from adult female snakes and their offspring," Toxicon, vol. 29, no. 2, pp. 219-226, 1991.

[39] J. L. López-Lozano, M. V. De Sousa, C. A. O. Ricart et al., "Ontogenetic variation of metalloproteinases and plasma coagulant activity in venoms of wild Bothrops atrox specimens from Amazonian rain forest," Toxicon, vol. 40, no. 7, pp. 9971006, 2002.

[40] R. A. P. Guércio, A. Shevchenko, A. Shevchenko et al., "Ontogenetic variations in the venom proteome of the Amazonian snake Bothrops atrox," Proteome Science, vol. 4, article 11, 2006.

[41] A. Zelanis, J. de Souza Ventura, A. M. Chudzinski-Tavassi, and M. D. F. D. Furtado, "Variability in expression of Bothrops insularis snake venom proteases: an ontogenetic approach," Comparative Biochemistry and Physiology C, vol. 145, no. 4, pp. 601-609, 2007.

[42] J. Monteiro, "Relação da Província do Brasil," in História da Companhia de Jesus no Brasil, S. Leite, Ed., Instituto Nacional do Livro, Rio de Janeiro, Brazil, 1949.

[43] I. Sazima, "Natural history of the jararaca pitviper, Bothrops jararaca, in southeastern Brazil," in Biology of the Pitvipers, J. A. Campbell and E. D. Brodie, Eds., pp. 199-216, Tyler, Selva, Spain, 1992.

[44] T. R. F. Janeiro-Cinquini, "Variação anual do sistema reprodutor de fêmeas de Bothrops jararaca (Serpentes, Viperidae)," Iheringia Série Zoologia, vol. 94, pp. 325-328, 2004.

[45] P. K. Smith, R. I. Krohn, and G. T. Hermanson, "Measurement of protein using bicinchoninic acid," Analytical Biochemistry, vol. 150, no. 1, pp. 76-85, 1985.

[46] U. K. Laemmli, "Cleavage of structural proteins during the assembly of the head of bacteriophage T4," Nature, vol. 227, no. 5259, pp. 680-685, 1970.

[47] A. Shevchenko, M. Wilm, O. Vorm, and M. Mann, "Mass spectrometric sequencing of proteins from silver-stained polyacrylamide gels," Analytical Chemistry, vol. 68, no. 5, pp. 850858, 1996. 
[48] G. B. Domont, J. Perales, and H. Moussatche, "Natural antisnake venom proteins," Toxicon, vol. 29, no. 10, pp. 1183-1194, 1991.

[49] M. M. Thwin and P. Gopalakrishnakone, "Snake envenomation and protective natural endogenous proteins: a mini review of the recent developments (1991-1997)," Toxicon, vol. 36, no. 11, pp. 1471-1482, 1998.

[50] L. N. F. Darville, M. E. Merchant, A. Hasan, and K. K. Murray, "Proteome analysis of the leukocytes from the American alligator (Alligator mississippiensis) using mass spectrometry," Comparative Biochemistry and Physiology Part D, vol. 5, no. 4, pp. 308-316, 2010.

[51] C. Stegemann, A. Kolobov, Y. F. Leonova et al., "Isolation, purification and de novo sequencing of TBD-1, the first betadefensin from leukocytes of reptiles," Proteomics, vol. 9, no. 5, pp. 1364-1373, 2009.

[52] V. Ignjatovic, C. Lai, R. Summerhayes et al., "Age-related differences in plasma proteins: how plasma proteins change from neonates to adults," PLoS ONE, vol. 6, no. 2, Article ID e17213, 2011.

[53] C. W. Vogel, D. C. Fritzinger, B. E. Hew, M. Thorne, and H. Bammert, "Recombinant cobra venom factor," Molecular Immunology, vol. 41, no. 2-3, pp. 191-199, 2004.

[54] S. Rehana and R. Manjunatha Kini, "Molecular isoforms of cobra venom factor-like proteins in the venom of Austrelaps superbus," Toxicon, vol. 50, no. 1, pp. 32-52, 2007.

[55] P. Hensley, M. C. O'Keefe, and C. J. Spangler, "The effects of metal ions and temperature on the interaction of cobra venom factor and human complement Factor B," Journal of Biological Chemistry, vol. 261, no. 24, pp. 11038-11044, 1986.

[56] R. H. Valente, B. Dragulev, J. Perales, J. W. Fox, and G. B. Domont, "BJ46a, a snake venom metalloproteinase inhibitor isolation, characterization, cloning and insights into its mechanism of action," European Journal of Biochemistry, vol. 268, no. 10, pp. 3042-3052, 2001.

[57] T. C. Antunes, K. M. Yamashita, K. C. Barbaro, M. Saiki, and M. L. Santoro, "Comparative analysis of newborn and adult Bothrops jararaca snake venoms," Toxicon, vol. 56, no. 8, pp. 1443-1458, 2010.

[58] F. R. Mandelbaum and M. R. Assakura, "Antigenic relationship of hemorrhagic factors and proteases isolated from the venoms of three species of Bothrops snakes," Toxicon, vol. 26, no. 4, pp. 379-385, 1988.

[59] M. J. I. Paine, H. P. Desmond, R. D. G. Theakston, and J. M. Crampton, "Purification, cloning, and molecular characterization of a high molecular weight hemorrhagic metalloprotease, jararhagin, from Bothrops jararaca venom. Insights into the disintegrin gene family," Journal of Biological Chemistry, vol. 267, no. 32, pp. 22869-22876, 1992.

[60] M. I. Estevão-Costa, B. C. Rocha, M. de Alvarenga Mudado, R. Redondo, G. R. Franco, and C. L. Fortes-Dias, "Prospection, structural analysis and phylogenetic relationships of endogenous $\gamma$-phospholipase $\mathrm{A}_{2}$ inhibitors in Brazilian Bothrops snakes (Viperidae, Crotalinae)," Toxicon, vol. 52, no. 1, pp. 122129, 2008.

[61] P. G. Hains and K. W. Broady, "Purification and inhibitory profile of phospholipase $A_{2}$ inhibitors from Australian elapid sera," Biochemical Journal, vol. 346, no. 1, pp. 139-146, 2000.

[62] A. Shimada, N. Ohkura, K. Hayashi et al., "Subunit structure and inhibition specificity of $\alpha$-type phospholipase $\mathrm{A}_{2}$ inhibitor from Protobothrops flavoviridis," Toxicon, vol. 51, no. 5, pp. 787796, 2008.
[63] A. M. Soares, S. Marcussi, R. G. Stábeli et al., "Structural and functional analysis of BmjMIP, a phospholipase $A_{2}$ myotoxin inhibitor protein from Bothrops moojeni snake plasma," Biochemical and Biophysical Research Communications, vol. 302, no. 2, pp. 193-200, 2003. 

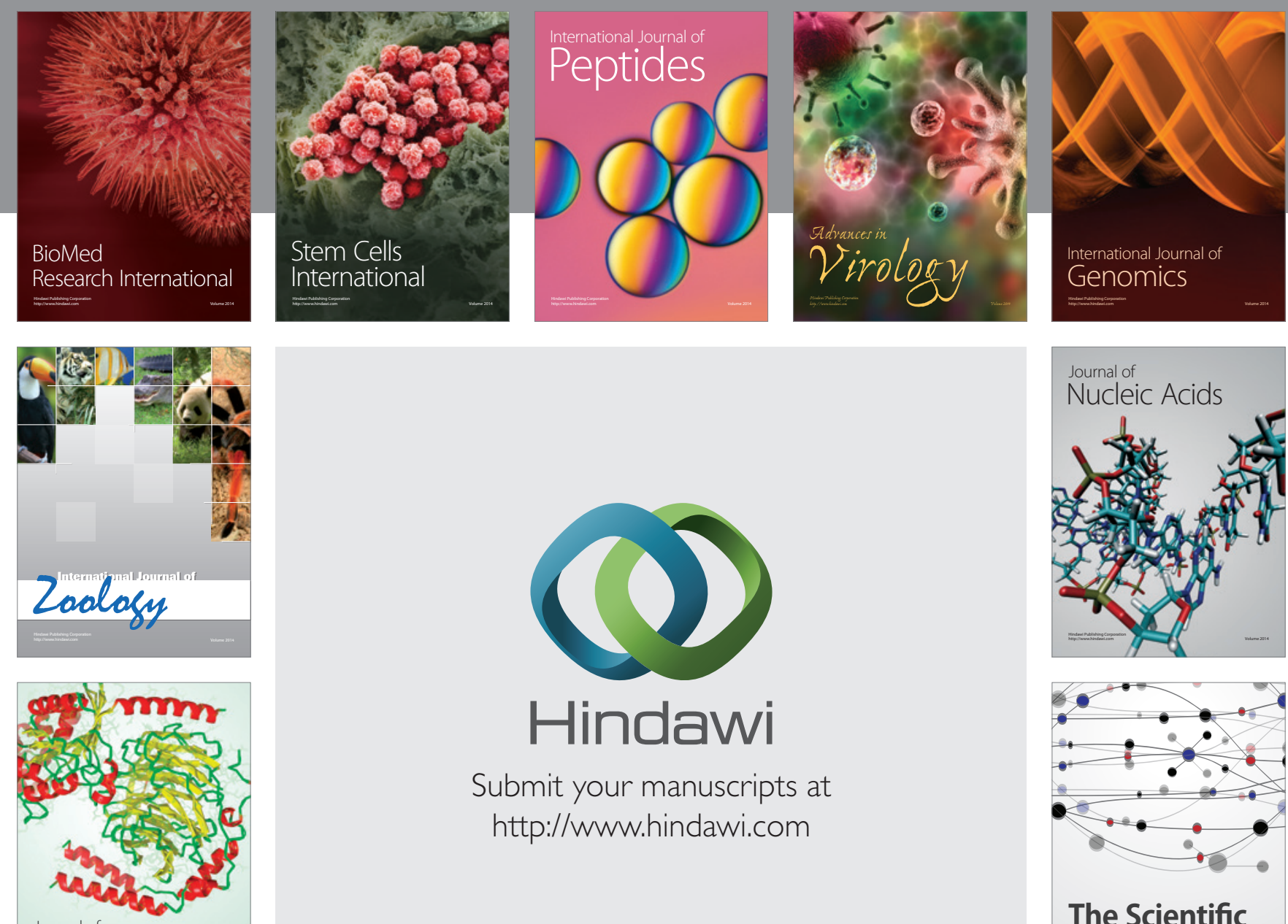

Submit your manuscripts at

http://www.hindawi.com

Journal of
Signal Transduction
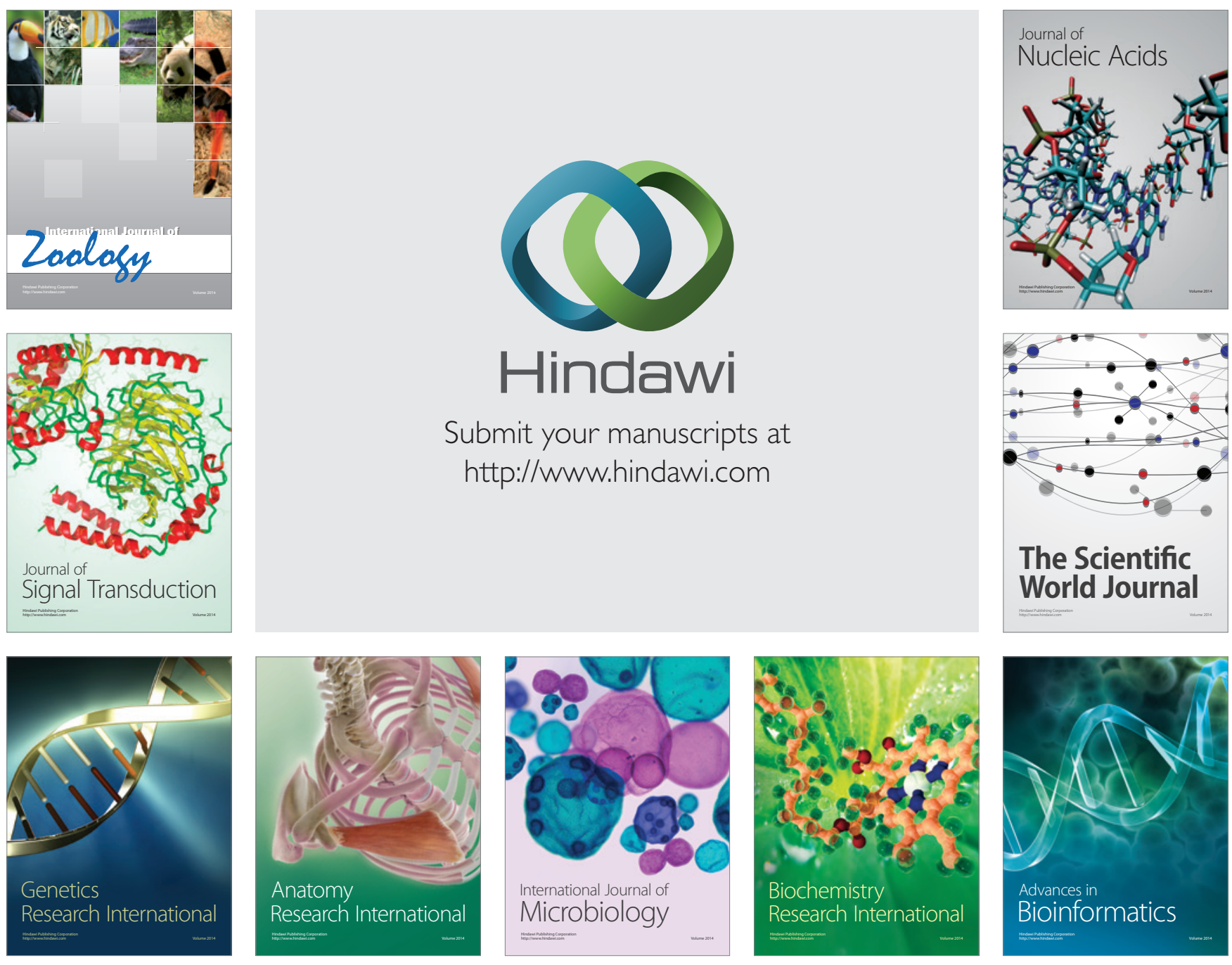

The Scientific World Journal
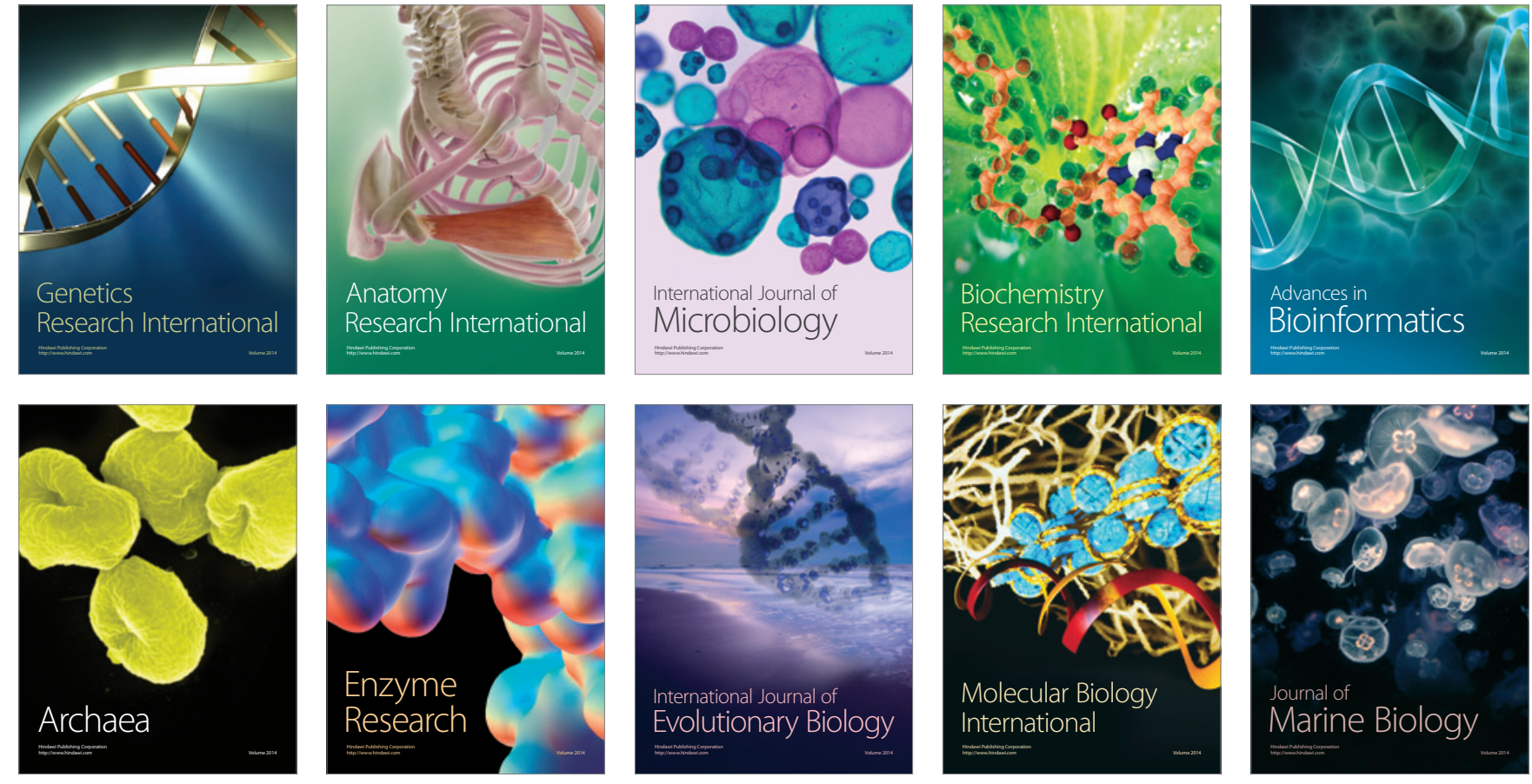